\title{
JANÅČEK'S AESTHETICS
}

\author{
Jaroslav J i ánek (Praha)
}

When considering the aesthetics of composers we always examine their writings and other linguistic documents, as well as their compositions as the ultimate result of their creative approach. Janáček's case is particularly interesting, because - contrary to other composers Janáček was extremely active in the literary sphere practically throughout his whole life. His literary heritage is rich as regards genres, including as it does 1) belletristic works (feuilletons), 2) critical and pedagogical articles, 3) essays on musicology and ethnography, 4) and a number of memoires and autobiographic material. It is interesting to compare Janáček's aesthetic opinions contained explicitly in his theoretical works and implicitly in his artistic expressions, both musical and literary. A part of Janáček's literary heritage has already been processed and appraised by experts whose works can now be taken as a base for further research. I have in mind the studies of Arne Novák (Leoš Janáček spisovatel - Leoš Janáček the Writer in: Janáček, L., Fejetony z Lidových noviny - Feuilletons from The People's Newspaper, Brno 1958), Vladimír Helfert (Kořeny Janáčkova kritického stylu - The Roots of Janáček's Critical Style - same source), Pavel Eisner (Janáček spisovatel - Janáček the Writer Hudbení rozhledy - Music Review - 11, 1958) and Antonín Sychra (Janáčkův spisovatelský sloh klíč $\mathrm{k}$ sémantice jeho hudby - Janáček's Style as a Writer the Key to the Semantics of His Music - Estetika - Aesthetics - 1, 1964). I think it is possible to agree with the conclusions at which all of them almost unanimously arrived. Janáček was unquestionably a real artist also as a writer. In the literary sphere, too, he manifested himself as a modern author on the boundary between impressionism and expressionism with the accent rather on the latter. At the same time, however, he wholly preserved his individuality, forming his fundamental creative base in his personal conception of folk realism. However, if we are to proceed further in our deliberations on Janáček's aesthetics, we must try to compare Janáček's complexly conceived work as a writer with his equally com- 
plexly conceived work as a composer. Moreover, we must, in particular, try to define the Janáčekism concept, i. e. Janáček's artistic style and his personal aesthetics, genetically and historically.

A. Novák was right in placing the phenomenon represented by Janáček on the historical cross-roads of style epochs. It was not, however, merely the question of the boundary between impressionism and expressionism; in his music there is also the boundary between neoClassicism, neo-Baroque and neo-folklorism. Janáček was intensely concerned with problems of the artistic trends of the $20^{\text {th }}$ century and keenly followed the development of world art, agreeing with some things and disagreeing (more often!) with other things. He was a modern man, but always wholly individual. Eisner's statement to the effect that it is not easy to decide what is dialectism and what is neologism in the case of Janáček is more far-reaching than the writer himself may have presumed. It is not the question merely of Janáček's literary stylistics, but directly the key question of Janáček's artistic style in general. ${ }^{1}$ Janáček cannot be wholly ranked in musical impressionism, expressionism or neo-Classicism and the artistic trends connected with them. Similarly as Otakar Ostrčil and Ladislav Vycpálek, Janáček was an intrinsically modern, but simultaneously specifically Czech personality representing a synthesis of style par excellence which cannot be explained at all without the historical logics of its home provenience. ${ }^{2}$

Janáček was a real Czech, more precizely a Moravian; in studying his specific personality we cannot overlook the historical background of the inequable development of Bohemia and Moravia.

While at the turn of the $18^{\text {th }}$ and $19^{\text {th }}$ centuries Prague was enchanted by the art of Mozart, Brno was still captivated by fashionable Viennese goods of the type of Müller, Süssmayer and others. While the typical features of the so-called ancien régime (aristocratic orchestras and a cosmopolitan bent for Italian opera) disappeared in Bohemia approximately at the beginning of the $19^{\text {th }}$ century, they survived in Moravia for another good thirty to forty years. The belated politico-

1 Attempts have been made to solve the problem of Janáček's originality of style onesidedly in the sense of its "dialectism". One of such attemps - incorrect due to their non-dialectic onesidedness - is, for example, Dietmar Ströbel's study Auf der Suche nach Janáčeks musikgeschichtlichen Ort, Colloquium Musica Bohemica et Europea, Brno 1970, Brno 1972, pp. $397-406$.

2 I tried to outline the genesis and synthetic nature of Janáček's artistic style in my study Leoš Janáček jako stylový mikrokosmos české hudby 20. století (Leoš Janáček as a Microcosmos of Style in Czech Music of the 20th Century), Hudbení věda (Musicology), 6, 1969, pp. 150-171. - Comp. also the paragraph on the formation of styles in the concluding chapter of Dějin české hudbeni kultury 1890-1945 (The History of Czech Music Culture 1890-1945), vol. I, Prague 1972, vol. II in print at the Academia Publishing House. 
economic development of Moravia could not but have natural consequences also for the specifically different course of the national revival in Moravia. In Bohemia the process of the bourgeois democratic revolution had progressed to such an extent that the development of the national revival had entered its second phase, marked by the fact that towns were ever more becoming centres of the patriotic movement (from where Czech national consciousness spread back to the countryside). In Moravia it was the other way round. Prague was just beginning its victorious struggle on the part of feudally desintegrated Moravia, as the revival had not as yet reached the towns from the countryside. This of course involves music as well. When in Bohemia the idea of romantism showed itself to be exceptionally fruitful and continued from folk art to the monumental attitudes of Smetana, in Moravia it stagnated on the level of the ideal of simple national folk art, represented most outstandingly from the artistic viewpoint by Kř́žkovský and developed theoretically by the folkloristic movement.

This naturally forms the historical basis of our explanation ${ }^{3}$ as to why Janáček, firmly rooted in his native Moravia, was remote from the romantic ideal of Smetana's programme music and the aesthetics of Otakar Hostinský and why he was closer to the formalistic Herbartian aesthetics of Durdík and Zimmermann.

On this basis we explain why the artistic world of Dvořák with its folk-like spontaneous directness and formal conservativeness was far closer to the young Janáček than the musically and ideologically exacting, reflective and formally new type of art of Smetana.

However, this historical "Moravian heritage" also had its positive aspects for Janáček, these being manifested in the remarkable dialectics of "dialectism and neologism", conservativeness and progress. He could approach the then new European trendis (impressionism, expressionism and so on) without the burden of romantism. Not even when seeking scientific answers to his questions - and Janáček sought them throughout his whole life - was he burdened with the speculative heritage of German idealistic philosophy. He also had no prejudices (after overcoming the dogmatism of Zimmermann and Durdík) opened up by the new, positivistically empiric trends, concretely Wundt's psychology and modern ethnographical study. A lifelong fondness for psychology and extensive ethnographical work were really inseparable attributes of Janáček's artistic personality. His interest in psychology primarily oriented him towards the means of

3 The possible objection to the effect that in the Eighties and Nineties the politico-economic situation in Moravia was quite different and that by then the high degree of inequability of the process of development had been smoothed out is not justified in this case. Moreover, the ideological superstructure manifests itself through its natural belatedness, so that Janáček just as a musician with Moravian feelings could follow only the trend set by Křížkovský and the folkloristic movement. 
expression (often at the cost of a formal system) and necessarily from here to the encroachment of art on man's inner world. His modern ethnographical approach was again oriented towards the depiction of a song in the concrete totality of the general life of mankind. ${ }^{4}$ Thus in fact from art to life once again. Both tendencies, the psychological and the ethnographical one, had an entirely synergical influence in this respect. A qualitative leap ahead then came about in Janáček's process of development when - favourably predisposed in this way he placed himself at the head of the powerful wave of artistic realism of the Eighties and Nineties and in particular of Russian literary realism. It was just in this sphere that Janáček found fertile soil for the creative development of the most intrinsic forces of his artistic talent and his artistic belief which had grown from the environment of his native Moravia. Here another path of escape from the mechanical folkloristic approach, in whose existence he firmly believed, presented itself to him, i. e. the path represented by psychological thinking out to the end and deepening of folk songs and language whose intonation fund was simultaneously to serve as a starting point in the creation of artistic pictures of life. Yes, it was at this point that, on the basis of his important, new appraisal, not the folk song and folk customs, but directly the language of the people won the leading place in Janáček's musically realistic observation of life. Here we find ourselves at the roots of Janáček's mature style of life solely from which we can deduce Janáček's aesthetics, the style which he later took for the theoretical justification of his so-called speech-melody theory.

Our consideration of the historical genesis of Janáček's creative personality and his aesthetics would not be complete, however, if we ignored the general factor represented by his East European orientation. The fact that the national revival struggle had not yet been won in the process of the bourgeois democratic revolution in Moravia and that new tasks of the class struggle of the working people against the bourgeoisie had arisen explains the conditions which in Janáček gave rise to the national and, in the real sense of the word, social unity so characteristic of him even if we do not know directly of his socialist civil conviction. ${ }^{5}$ But his concern about the unsolved and, in the conditions of the then capitalist society, ever more complicated problems of the countryside was shared by the intelligentsia of all the formerly

4 Comp. his characteristic statement: "The folk song is, as a beautiful language, dependent on the place where it is sung, on the time at which it is sung, on the occasion on which and in the mood in which it is sung. It changes into an air and interjections when these circumstances are changed." Quot. after Janáček, L., O lidové pisní a lidové hudbě (Folk Songs and Folk Music), Prague 1955, p. 291.

5 After the première of Maryčka Magdónová someone is alleged to have said to him: "That Maryčka, she's a socialist meeting!" To this Janáček replied: "Yes, that's what I wanted!" Quot. after Šeda, J., Leoš Janáček, Prague 1961, p. 28. 
prevailingly agricultural countries of East and South East Europe. The wave of vital ethnographical interest, which in this country reached its climax at the time of the Ethnographical Exhibition (Prague 1895) and also had a favourable influence on Janáček, as mentioned previously, was its theoretically greatly mediated scientific reflex. Herein lies the more general bond which links, through their shared ethnographical interest, Janáček with Bartók, Kodály and Enesco, but which - in spite of all concrete historico-social pecularities and national and regional differences - links him with the East European personalities also from the viewpoint of musical composition. ${ }^{6}$

After overcoming the influence and later reoccurrence of romantism, Janáček consciously left the traditional soil of Central European musical development and turned to the inexhaustible wealth of East European folklore culture, in particular to that in Moravia. The historical greatness of his chosen task best comes to light if we compare, for example, the traditionally romantic opera Sárka with the folkloristic opera The Beginning of a Novel and the folk ballet Rékos Rákoczy whose belated, in fact still pre-romantic folklorism could not, due to their primitiveness, hold their ground artistically in the competition of the mature classico-romantic technique which had been developed throughout whole centuries on the basis of European experience. Janáček's brilliance lies in the fact that he did not consequently allow himself to be led to the mechanical adoption of this mature West European technique and that - as Mussorgsky had done before him - he placed in all seriousness the problem after the expedience of the West European path of intellectualization of the home folklore whose roots lay entirely elsewhere. The mature technique of West European music culture developed historically, being based on its own material, originally also home folk musical imagination. The difference which arose here is connected with the inequable process of cultural-historical development which divided the cultural nations of Europe into those which had created their own mature artificial music culture several centuries earlier and those, especially in East and South East Europe, in whose case it was still possible in the $1^{\text {th }}$ century to trace the organic continuity of the national tradition only in folk music. ${ }^{7}$ In this cultural-historical environment the

6 Comp. Vancea, Z., Janáček und die führenden Komponisten der südosteuropäischen Schulen: Bartók, Enesco, Koldály, in: Leoš Janáček a soudobá hudba (Leoš Janáče'k in Contemporary Music), pp. 330-344.

7 Zeno Vancea quotes in this respect Kodálý's remarkable statement: "The justification of the existence of folk music does not end with the fact that it satisfies the need of the people. It also has a connection with the present life of us all and contains the core, the plan of a great music culture. The development and consummation of this culture are the task of the cultured masses. However, the force which is necessary for this can result only from complete unity with the people. In order that we may be a nation we must in the first place be people. This means that for us 
natural need arose in the process of creating a modern national musical language of intellectualizing the home musical folklore material in a likewise individual way, i. e. by means of a corresponding technique, in the manner which we encounter in the case of the Hungarian composer Kodály, the Rumanian composer Enesco, but also Bartók and the young Stravinský, the Polish composer Szymanowski, the Slovak composer Suchon and others. Even in the 19th century all these found an example in Mussorgsky and our Janáček who even in the conditions of the proved pan-European historical continuity of their national cultures rejected the idea of the mechanical adoption of the West European musical technique and endeavoured to develop an entirely special technique generalizing the characteristic folk musical material of their own regional environment. ${ }^{8}$

The basic chauracteristics of Janáček's East European musical conception can be summarized clearly and briefly in approximately the following points:

1. In the West European musical language, which had undergone a process of emancipation roughly from the Baroque epoch, the instrumental type of melodic invention finally prevailed, while in Janáček's music, on the contrary, vocal-melodic invention prevails even though his typical "interjections" are instrumentally figurative in nature.

2. While West European music of the $17^{\text {th }}, 18^{\text {th }}$ and $19^{\text {th }}$ conturies is marked by tonally harmonic musical thinking, Janáček's musical language is characteristically marked by a wealth of musical modality.

the tradition of folk music signifies incomparably more than for the western cultured nations which created highly valuable artificial music whole centuries ago. In their case folk music changed long ago into artificial music and in the work of their great masters we can find that which at present we have only in our folk music, i. e. organic continuity of the national tradition."

${ }^{8}$ In this connection it is interesting to quote also the opinion of $\mathrm{B}$. V. Asafyev expressed in 1925 in his study Contemporary Russian Musicology and Its Historical Tasks: "... in the West European musical material fund and the method of its processing the technique of the shaping process has developed to such an extent that there is nothing to master. There is only one starting point: the unavoidableness of enlarying the number of possible sound structures and sound relations, either by an invasion of new, fresh material, or by the spreading of tempered systems. Such is the situation in the West. In our country this crisis is felt, on the contrary, partly by an imperfect awareness of our own intonation systems and partly by the mechanical application not only of technical procedures, but also of processing methods foreign to our characteristic musical material." He then arrives at the conclusion that the qualitative contribution of Russian music culture cannot be secured in any other way than by ensuring that individual Russian musical material is intellectually processed in an equally individual and specifically corresponding way. 
3. In comparison with West European tectonics of an evolutionary type, Janáček's central tectonic principle is based on the suite which suited better his realistic aesthetic ideal and his need of plastic, "almost statically tangible" figurativeness.

4. Closely connected with this is the striking difference in his structure, because compared with the traditional vertical differentiation of the harmonico-polyphonic structure of West European music, Janáček's musical expression is also vertically complex in nature. This complexity of sound, growing from the base formed by the heterophony of folk music and from a vertical combination of melody and "interjections", is the source of the timbre and tone effects of Janáček's music.

5. A contrast to the vertical sound complexity of Janáček's musical expression consists in his striking differentiation in the horizontal plane, i. e. his considerable degree of looseness in the fields of metre, agogics and tempo, characteristic of the free musical vocal expression and the rhapsodical style of play of folk musicians. In this case, too, it is the question of a typologically antithetic speciality, because West European music always inclined, on the contrary, to considerably complex metric stabilization in the horizontal plane.

6. Janáček's musical language manifests certain residues of archaic musical procedures in the field of intonation (analogous to the archaic verbal turns of speech à la "ažtma" ("up to darkness") to which. P. Eisner drew attention), for example, a characteristic melodic ductus on the basis of a fourth-fifth distributing of the octave. ${ }^{9}$

Of aesthetic relevance, however, are the hierarchization, concretization and individualization of his musical language reaching almost as far as style. A systematic analysis of the style of Janáček's representative musical works, to which only reference can be made here, ${ }^{10}$ showed that Janáček's musical work represents, in its way, a microcosmos of Czech music of the $20^{\text {th }}$ century due just to its style. Features in common with impressionism and to an even greater extent with expressionism can easily be demonstrated also in his musical work, but his individual musical realism remains the organic, binding and synthetizing force of the style of all his musical expression. The si-

9 Attention was once drawn to these by V. Lébl who ranked them, incorrectly in my opinion, among melodies which are wholly freeing themselves from their mother origin of speech melodies in order to become an entirely superior musical element, a kind of idée fixe penetrating through a whole work..." Comp. Läbl, V., Diskusní př́spěvek $k$ referátüm o Janáčkově nápěvkové technice (Discussion Contribution With Regard to Papers on Janáček's Speech Melody Technique), quot. coll. Leoš Janáček a světová hudba (Leoš Janáček and World Music), pp. 202-203 with musical example.

10 Comp. note No. 2 above. 
milarity of his musical style and the style of his literary expressions is really conspicuous (the opinions expressed by A. Novák, P. Eisner and particularly A. Sychra in this respect were wholly correct) and his speech melody "aesthetic creed", winding its way like a red thread through his literary work in both fleeting and more fundamental formulations, is the main connecting medium of this similarity.

In both its positive and negative aspects, Janáček's speech melody theory is also the most characteristic expression of Janáček as a theoreticizing composer and the most characteristic model of his theoretical thinking. Janáček's scientific interest in speech can roughly be defined by saysing that he was concerned with the syntagmatic rather than the paradigmatic plane, with "parole" rather than "langue", in so far as we can say that he was interested in speech as a language. Definitely closer to the truth will be the statement that Janáček was interested in speech not as a linguistic utterance, but as a sound document of extralinguistic situations, as an immediate sound expression of the human psyche. This affords an explanation to the question of why his approach to live speech was of a phonetic and not phonological nature $^{11}$ and why Sychra was able to prove conclusively through his analysis that due to his stylistic procedures Janáček tended, also as a writer, to emphasize not the semantic aspect of the given text, but its direct expression. In the case of Janáčék absolutization of the psychological and under-estimation of the socio-institutional fact of speech communication were unquestionably connected with the contemporary influences of positivistic psychology, especially that propagated by Wundt (and with his exaggerated belief in Hipp's chronoscope!). His uncritical, almost too literal acception of Wundt's principle of the so-called psychophysiological parallelism also had an unfavourable influence on Janáček's musical theoretical thinking, concretely on his theory on harmony. Concerned here in particular is an unclearly de-

11 I had a previous opportunity (comp. my study Sémantické možnosti a meze hudby - The Semantic Possibilities and Limits of I Iusic - Estetika - Aesthetics, 12, 1975, pp. 77-107) to draw attention to Janáček's polemics with Hostinský on the subject of Czech musical declamation (in his review of Kuba's collection Slovanstvo ve svých zpěvech - The Slavs in Their Songs), reprinted in the quot. coll. O lidové pisni a lidové hudbě (Folk Songs and Folk Music), pp. 129-131. Hostinský (O české deklamaci hudební - Czech Musical Declamation - Prague 1886) stood on a phonological base and Janáček on a phonetic one. Hostinský was right in so far as he drew attention to the influence of certain phonologically specific pecularities of the Czech language, for example, the accenting of short syllables at the beginning of a word which of necessity influences also the character of the musical declamation of the Czech language. Janáček, the hunter of "spjeech melodies", was in turn, due to his viewpoint, close to recognizing and understanding the practically unlimited possibilities of the emotional sub-text of spoken language. Phonological elements naturally forced themselves on Janáček as well, doing so, however, wholly elementally in the dialect form of his "short" dialect. 
fined differentation or incorrect confusion of the purely physiological and psychological after-effects in Janáček's "pacit" and "spletna",12 intermediated (by underestimation of or wholly inadequate respect for the socially institutionalized field of paradigmatics) by Janáček's refusal to recognize the harmonic units of a chord and his founding of the interpretation of harmonic phenomena on a mere expressional "link" of different tones. Ranking here is also his analogous interpretation of modality (so typical of Janáček the composer!), upon which he likewise looked purely psychologically as an "alteration", denying its historical connection with old (so-called church) keys. ${ }^{13}$

It is an indisputable fact that these theoretical ideas were reflected not only in Janáček's musical compositions, but also in his literary works - as we have seen. What else led Arne Novák to overestimate the impressionistic elements in Janáček than his psychological fetishization of a moment - even if in scientific accord with Hipp's chronoscope? And what else led Sychra to define the basic subjectivization trend of Janáček's prosaic style if not an endeavour to capture both a momentary psychic detail and the psychological depiction of given extra-speech situations as truthfully as possible? And what other meaning has Janáček's indefatigable collection of speech melodies than a desired empiric base for his work as a composer?

Janáček was greater, however, as an artist than a theoretician and the aesthetics inherent to his work as a composer are more legitimate than the aesthetics of his written theoretical (not to the extent of his belletristic) works. For this reason, when Sychra speaks about the modern shifting of accents to the subject and a general shift from the objective to the subjective as a stylistic trend heading towards the psychologically most truthful depiction of even incidental speech situations (which is definitely correct), we begin to deliberate on the question of whether this characterization is complete. True, Sychra

12 I am unable to clarify here Janáček's characteristic musico-theoretical terminology, likewise tributary to the mentioned dialectics of his dialectisms and neologisms. I should therefore like to draw attention to the dictionary of Janáček's terminology compiled by Z. Blažek, in: Janáček, L., Hudebně teoretické dílo (Janáček, L., His IMusico-Theoretical Wor'k), 1, Prague-Bratislava 1968, pp. 47-51. - As far as specialized literature is concerned, I should like to draw attention particularly to Chapter 13 of Volek's book Novodobé harmonické systémy z hlediska vědecké filozofie (Modern Harmonic Systems from the Aspect of Scientific Philosophy), Prague 1961, pp. 231-277, which in my opinion affords the best explanation of Janáček's theory on harmony. Jaroslav Volek also correctly draws attention to the previously mentioned unfavourable influence of Wundt, lc., p. 257.

13 The question of the theoretical and historical justification of such an interpretation was also raised by Jiří Vysloužil; comp. Janáčkova tvorba ve světle jeho hudebně folkloristické teorie (Janáček's Work in the Light of His Musico-Folkloristic Theory), in: quot. coll. Leoš Janáček a soudobá hudba (Leoš Janáček and Contemporary Music), lc., p. 365. 
also speaks about the dramatized structure of the intonation of a movement in the case of Janáček and draws attention in the previously mentioned way to "a dialogue in a dialogue" in the opera From the House of the Dead, but he does not devote adequate attention to Janáček's trend to dramatize (in our opinion as equally important as his trend towards a "speech-like" style). After the subjectivization of artistic utterances, Janáček's indisputable elements of dramatization are a very effective instrument of re-objectivization. It is quite true that, with his characteristic technique employing ostinatos, repetition, varation and figuration, Janáček aimed at expressing a moment directly and with the greatest possible degree of psychological veracity also in his music (and this procedure also represents the basic source of all the expressionistic elements in his works as a composer), but he never stopped at this. His figurations are never "merely figurations", but have the character of thematic figurations whether they originated as the result of dethemization or, on the contrary, just new thematization. And in the case of Janáček this is of profound aesthetic import. ${ }^{14}$

It is certainly not just a matter of chance that the focal point of Janáček's work as a composer - as is now generally recognized lies in his operatic, musically dramatic works. Janáček really did also create a new style in $20^{\text {th }}$ century opera and found followers also abroad (for example, B. Britten in some of his operas). Janáček's musical works do not, however, deny a strong dramatic charge, this applying also to his purely instrumental compositions, even piano ones where this could perhaps be least expected. A very sharp contrast, often achieved by means of a striking change in the expression of decisive sub-intonation factors (melody and its type, dynamics, tempo and agogics, rhythm, structure, phrasing and so on), is also characteristic of his purely instrumental works. And thus Janáček's piano compositions are also marked by that special corrugated and interrupted sound and striking contrast of expression which usually accompany a really dramatic plot. Not only this outer characterization is concerned here, however. Otakar Hostinský, who concerned himself with the aesthetics of the drama and »the dramatic « practically throughout his whole life, arrived at two very substantial postulates of "the dramatic": the requirement of "bodily" actualization (directly accessible to and graspable by our senses) of a given plot and the requirement of a strict causal structure of this plot. On the basis of the example represented by Our Lady of Frýdek it would be possible to demonstrate the way in which Janáček succeeded in a directly physical manner in actualizing his musical description by means of

14 I recently dealt with this problem in greater detail in my study Dramatické rysy Janáčkova klavírního stylu (The Dramatic Features of Janáček's Piano Style), Opus musicum, 10, 1978, Nos. 5-6, to which I should like to draw attention here. 
psychologically uniquely graded ostension based purely on sound. It would also be possible to draw attention to the way in which he succeeded in dramatically actualizing his musical pictures by revealing consistently inner antitheses leading to open conflicts as well. What else is Janáček's method of dethematization and regressive or new thematization of his characteristic instrumental figurations if not an index representation of the theme in the first and a figuration in the second case? And since in Janáček's piano style instrumental figurations and a cantabile theme represent extreme expressional antitheses, the contrasting turns achieved by their means acquire the character of dramatic conditioned conflicts with an innearly strict causal structure. In this respect even Janáček's piano works are dramatic in the real sense of the word and his piano style can be described as dramatic also in this aesthetically strictest sense.

The general wealth of Janáček's realism as the backbone of his mature artistic style is also clearly connected with the almost explosively dramatic dynamism of the composer's artistic talent. Mention is often made of his "wealth of genres", his "tendency towards social criticism", his "psychological depth" and even his "ethical nature" (Sychra). All these perceptions are unquestionably correct and all of them can be documented, but Janáček's artistic realism cannot be reduced purely to a single one of them. Janáček's realism is a fact which is as equally dynamic as it is indisputable, because Janáček was spared the fate of those composers who - after having arrived at an individually defined style - did nothing more than merely enhance it quantitatively, thus creating something of the nature of an "encyclopaedia of their own already finished work". Janáček was different! He was always individual, but always new. And the continuity of his style was strikingly dynamic. I think that this was due to the profound, previously explained and, in this respect, blessed inner antagonism of his creative nature, an antagonism in which the tension between a theoreticizing observer and an earthly, spontaneous artist did not play the smallest role. The triumph of artistic deeds over the aesthetics of theoreticizing ideas and words is more than understandable in the case of an artist of Janáček's stature and weight.

English Version by Joy Turner-Kadečková

\section{POVZETEK}

Empirična baza za razmišljanje o Janáčkovi estetiki je primerjava njegovega skladateljskega in pisateljskega dela. Slednje obsega Janáčkovo literarno (beletristično), kritično in pedagoško ter znanstveno dejavnost (glasbeno-teoretsko, folkloristično oziroma etnografsko). Pričujoče mnenje se veže na dosedanje študije A. Nováka (Leoš Janáček spisovatel, v: Fejetony z Lidovych novin, Brno 1958), V. Helferta (Kořeny Janáčkova kritického 
stylu, ib.), P. Eisnerja (Janáček spisovatel, Hudební rozhledy, 11, 1958) in A. Sychre (Janáčkuv spisovatelský sloh 'klíč k sémantice jeho hudby, Estetika, 1, 1964). Sklepi, do katerih so prišli ti avtorji, so točni, zlasti, ker je bil Janáček umetnik tudi kot pisatelj. Tudi $v$ literarni smeri je dokazal moderni pristop $\mathrm{v}$ smeri med impresionizmom in ekspresionizmom $\mathrm{z}$ naglasom na drugem, hkrati pa ohranil svojo individualnost, ustvarjajoč svoj umetniški fundament na temelju pètega ljudskega realizma. J. Jiránek primerja Janáčkovo kompletno pisateljsko in skladateljsko delo in skuša omejiti »janáčkizem《, Janáčkov umetniški stil in njegovo individualno estetiko genetsko in historično. Zrelega Janáčka uvršča tja, kjer so Musorgski, Kodály, Bartók, mladi Stravinski, Szymanowski in Suchoñ v kontekstu vzhodnoevropske kulture, in naznačuje njegov vzhodnoevropski koncept $v$ naslednjih temeljnih točkah: 1. V zahodnoevropski glasbi, kakor se je emancipirala od baroka dalje, je ob koncu prevladal instrumentalni tip melodične invencije, $v$ Janáčkovi glasbi pa dominira vokalna melodična invencija, čeravno je občasno instrumentalno figurativna; 2. medtem ko je zahodnoevropska glasba 17. do 19. st. tonalno hormonična, je za Janáčka značilno bogastvo glasbene modalitete; $3 . \mathrm{V}$ primerjavi $\mathrm{z}$ zahodnoevropsko tektoniko evolucijskega tipa sloni Janáčkov osrednji tektonski princip na suiti, ki bolj odgovarja njegovemu realističnemu estetskemu idealu in njegovi potrebi po plastičnosti; 4. z vertikalno zvočno kompleksnostjo Janáčkove glasbene strukture kontrastira njegova diferenciranost $s$ horizontalnega vidika, metrična in agogična sproščenost, ki je značilna tudi za tempe. Tudi $v$ tem primeru gre za nasprotno tipološko lastnost, ker je zahodnoevropska glasba vselej inklinirala obratno, $\mathrm{v}$ horizontalnem oziru $\mathrm{k}$ razvidni kompleksni metrični stabilizaciji; 5. Janáčkov glasbeni jezik kaže nekatere ostanke arhaičnih glasbeno intonacijskih postopkov, na primer karakteristični melodični duktus na temelju kvartkvintne razdelitve oktave.

Jiránek meni, da je teoretični ključ k Janáčkovi estetiki v njegovi teoriji napeva, $\mathrm{v}$ njegovih pozitivnih in negativnih znakih. Janáčkovo znanstveno zanimanje za govor je mogoče definirati tako, da je posvetil pozornost bolj sintagmatičnemu kot paradigmatičnemu, bolj govoru kot jeziku, kolikor je sploh mogoče reči, da ga je govor interesiral kot jezik. Na govoru je bil zainteresiran predvsem kot na zvočnem dokumentu, šlo mu je za zvočni izraz ljudske psihe. To pojasnjuje, zakaj je bil njegov pristop $\mathrm{k}$ živemu govoru fonetičen in nikoli fonološki, in zakaj je lahko Sychra s svojimi analizami pokazal, da je Janáček $s$ svojimi stilnimi prijemi tudi kot pisatelj podčrtaval ne toliko semantično stran teksta kot prej njegov neposredni izraz. Janáčkova psihološka absolutizacija in podcenjevanje socialno pogojene strani komunikacije govora, to in ono je bilo verjetno odraz pozitivistične, posebno Wundtove psihologije. Nekritično, skoraj dobesedno prevzemanje Wundtovega principa t. i. psihofiziološkega paralelizma, je vplivalo tudi na Janáčkovo glasbeno-teoretsko miselnost, pa tudi na sicer zelo izvirno teorijo harmonije.

Vsekakor je bil Janáček večji umetnik kot teoretik, estetika njegovega skladateljskega dela pa je legitimnejša kot estetika njegovih literarnih del. Moderna subjektivizacija izraza je v Janáčkovem umetniškem delu upoštevana z močnimi značilnostmi dramatizma. Sklicujoč se na svojo študijo Dramatické rysy Janáčkova klavírního stylu (Opus musicum, 10, 1978) ugotavlja Jiránek navzočnost teh dramatskih faktorjev tudi $v$ tako subtilni vrsti, kot je 'klavirska tvorba tega skladatelja. Na splošno je mogoče reči, da je Janáčkov realizem posebno značilen močan dramatski dinamizem. Možno je predpostaviti, da je ta dinamizem zrasel pri Janáčku iz stalne napetosti med teoretikom in umetnikom. Razumljivo je, da je naposled zmagala estetika umetnostnih dejavnikov nad estetiko teoretično pogojene miselnosti. 